\title{
IMPERIALISMO MACEDÔNIO E COLONIALISMO FRANCÊS: O MUNDO HELENÍSTICO DE PIERRE JOUGUET ${ }^{1}$
}

\begin{abstract}
Thiago do Amaral Biazotto*
RESUMO: O helenista francês Pierre Jouguet (1896 - 1949) publicou seu estudo sobre Alexandre Magno e o Mundo Helenístico em 1926. De título L'impérialisme macédonien et l'hellénisation de l'Orient, a obra carrega matizes imperialistas modernos, presentes, em especial, quando Jouguet aborda os contatos culturais entre grego-macedônios e autóctones, limitados, em seu entendimento, a uma inconteste helenização dos últimos. Desta forma, este artigo discutirá a possibilidade de Jouguet projetar os anseios imperialistas da França moderna para o Mundo Antigo, notadamente quando são discutidas as relações culturais e o protagonismo das cidades gregas em sua obra.
\end{abstract}

PALAVRAS-CHAVES: Pierre Jouguet (1896-1949); helenismo, Historiografia.

\section{MACEDONLAN IMPERIALISM AND FRENCH COLONLALISM: THE HELLENISTIC WORLD BY PIERRE JOUGUET}

\begin{abstract}
The French hellenist, Pierre Jouguet (1896-1949), published his study on Alexander the Great and the Hellenistic World in 1926. Titled L'impérialisme macédonien et l'hellénisation de l'Orient, the work carries modern imperialist hues, especially when Jouguet discusses the cultural contacts between the Greek-Macedonians and the indigenous, limited, in his view, to an uncontested indigenou's Hellenization. Thus, this article will discuss the possibility of Jouguet project the imperialist desires of modern France to the Ancient World, especially when he discusses cultural relations and the greek cities' protagonism in his work.
\end{abstract}

KEYWORDS: Pierre Jouguet (1896-1949); Hellenism; Historiography.

\footnotetext{
${ }^{1}$ Pesquisa realizada com financiamento da FAPESP.
} 


\section{INTRODUÇão}

partir do último quartel do século XIX, a acumulação de capital e o assombroso
desenvolvimento da indústria lançaram as potências europeias a uma busca por
novos territórios nos quais pudessem obter tanto mercados consumidores como matérias primas a preços mais atraentes. Para que tal intento fosse levado a termo, contudo, era necessário mais do que o afã econômico; era de fatal importância a intervenção política, o controle formal dos longínquos confins desse admirável mundo novo. A união destas duas aspirações fez com que fosse inaugurada - nos termos de Eric Hobsbawm - a era dos Impérios.

Mesmo não sendo objetivo deste artigo a feitura de uma discussão aprofundada dos conceitos de imperialismo e império, é de bom alvitre apresentar algumas discussões a respeito de como tais ideias foram forjadas. Entre as muitas correntes, aqui opta-se por aquelas representadas pelo supracitado Hobsbawm e pelo intelectual palestino Edward Said. ${ }^{2}$ Hobsbawm advoga que o imperialismo surgido em fins do século XIX possuía novidades quando comparado àquele da Antiguidade: era caracterizado pela conquista sistemática associada à proliferação de colônias, de modo a garantir a preponderância da metrópole sobre os territórios assimilados. Assim, os rincões africanos e asiáticos foram repartidos de forma arbitrária entre potências capitalistas como Grã-Bretanha, França, Alemanha, Bélgica e outros (2005, p. 88). A maior destas potências, a Grã-Bretanha, não por acaso, foi o local de nascimento do termo imperialismo na era Moderna, para fazer referência aos Impérios Romano e Napoleônico. De acordo com Hammond (1948, p. 105), o vocábulo surge por volta da década de 1860, primeiro eivado de conotações negativas para depois - e como consequência da expansão marítima britânica e de a Rainha Vitória ser laureada com o título de "Imperatriz da Índia", em 1877 - ser tingido com tonalidades mais brandas.

Já Said assevera que o imperialismo moderno nasce do sedutor desejo de possuir terras que não estão sob nosso controle, um impulso para governar paragens exóticas e distantes. A reunião destes territórios heterogêneos sob o signo do poderio da metrópole formaria aquilo que se entende por Império. Imperialismo seria o processo por intermédio do qual se busca salvaguardar sua integridade, garantido o controle metropolitano sobre as mais longínquas terras (1995, p. 37). Assim, se Hobsbawm defende que a fundação colonial

\footnotetext{
${ }^{2} \mathrm{O}$ debate historiográfico em torno do conceito de imperialismo é vastíssimo, e seria impossível resumi-lo a dois ou três autores. Todavia, a opção por Hobsbawm e Said reside em dois fatores principais, a saber, ambos são autores de vasta influência dentro deste campo de debate e - o mais importante para o argumento deste artigo - é o fato de que a despeito de terem formações teóricas distintas - Hobsbawm era um marxista incontornável ao passo que Said faz fama com os estudos pós-coloniais -, ambos estão de acordo com a hipótese de que o imperialismo moderno se alicerçava e se representava tanto nas práticas culturais cotidianas quanto nas produções acadêmicas. Uma vez que o objetivo central deste artigo é identificar traços favoráveis à prática imperialista moderna delineados nos escritos de Jouguet sobre a Antiguidade, a escolha de dois pesquisadores de relevo que levaram a termo pesquisas nesta mesma direção parece fornecer a perspectiva teórica necessária.
} 
está no coração do imperialismo moderno, Said é mais comedido e a considera apenas mais uma das múltiplas práticas usadas para consolidação do poder imperial.

Se os dois pensadores discordam quanto ao papel das colônias, seus discursos são harmônicos quando abordam a retórica que permeava o imperialismo moderno. Hobsbawm propõe que era inegável "a ideia da superioridade em relação a um mundo de peles escuras situado em lugares remotos” (2005, p. 106-7), de modo que os europeus se enxergavam imbuídos da tarefa de converter os nativos à "verdadeira civilização, aquela representada por comerciantes, missionários e grupos de homens equipados com armas de fogo e aguardente" (2005, p. 118). Estava o imperialismo, em larga medida, carregado do desejo de “ocidentalizar" os autóctones (2005, p. 115). Já Said vai além: em seus esquemas, a força motriz mais notável por trás do fenômeno imperialista é a legitimidade no âmbito cultural, atingida mediante a retórica da inferioridade das colônias e seus habitantes, estigmatizados como possuidores de inteligência limítrofe, indivíduos primários, reles crianças que sem a tutela do homem branco ocidental estariam condenadas à mais soturna ignorância (1995, p. 40-2). Assim, não há imperialismo possível sem a presença de um lastro adquirível apenas no domínio cultural. A cultura dá sustento ao imperialismo. Eis o porquê do título do trabalho de Said, publicado em 1993.

De acordo com Renato Pinto (2011, p. 44), também ecoando Said, os termos mais comuns que adornavam este discurso imperialista eram "raça inferior", "povos subordinados" e "fardo civilizador". Impossível não se lembrar, no campo literário, do emblemático poema “The White Man's Burden”, publicado em 1899 por Rudyard Kipling, para se referir à missão dos Estados Unidos para com as Filipinas, colônia adquirida em 1898. Sua primeira estrofe bem resume como os europeus enxergam suas aventuras coloniais, conotações que muitas vezes foram refletidas nas obras sobre o Mundo Antigo publicadas àquela época. Escreve o bardo do império indiano:

Tomai o fardo do Homem Branco
Envia teus melhores filhos
Vão, condenem seus filhos ao exílio
Para servirem a seus cativos
Para esperar, com arreios
Com agitadores e selváticos
Seus cativos, servos e obstinados
Metade demônio, metade criança ${ }^{3}$

Assim, o imperialismo moderno foi de caráter político e econômico, mas talvez, sobretudo, de caráter cultural. O discurso europeu de que a civilização oriental e suas benesses seriam carregadas às remotas colônias é notório. Cabe investigar de que forma ele foi embasado e incutido em obras que emprestam o Mundo Antigo como objeto de estudo.

\footnotetext{
3 'Take up the White Man's burden/ Send forth the best ye breed/ Go send your sons to exile/To serve your captives' need/ To wait in heavy harness/ On fluttered folk and wild/ Your new-caught, sullen peoples/ Half devil and half child" (Tradução minha).
} 
Um volume que pode ter sido escrito com este propósito é o de Pierre Jouguet. Nascido a 14 de maio de 1869, em Bessèges, minúscula comuna francesa na região administrativa de Languedoc-Roussillon, Jouguet publicou em 1926 L'impérialisme macédonien et l'hellénisation de l'Orient ${ }^{4}$ que carrega em suas mais de cinco centenas de páginas um forte verniz imperialista, de tal forma que Funari (2003a, p. 40) sentencia: "As analogias entre o imperialismo francês e o macedônico seguramente não estavam longe das preocupações de Jouguet".

\section{A vida e os EStudos de PIERRE JOUGUeT}

Pierre Jouguet foi estudante da École Normale Supérieure - instituição das mais prestigiosas na França (Vidal-Naquet, 2004, p. 17) - de 1890 a 1893, rumando em seguida para a École Française d'Athènes, onde despertou interesse pelas escavações em Delfos. Diante da afeição do estudante, o então diretor da Escola, Théophile Homolle, envia-o para o Institut Français d'Archéologie Orientale du Caire. Lá, Jouguet permanece durante o biênio 1896-7, traduzindo pergaminhos de origem grega. Após participar de escavações em Ghorân (1990) e Tenheh (1903), o helenista retorna a Lille, funda seu Instituto de papirologia e começa a publicar os dez volumes dos Papyrus de Lille, em conjunto com outros pesquisadores, como P. Collart, J. Lesquier e M. Xonal.

Em 1911, Jouguet conclui sua tese de doutoramento de título La vie municipale dans L'Egypt romaine et les papyrus de Théadelphie. No mesmo ano, é convidado a assumir o cargo de professor de História Antiga e Papirologia na Faculté des Lettres de Lille, onde permanece até 1920, quando adentra aos panteões da Sorbonne, lá permanecendo até 1933 (Zeiller, 1949, p. 214). Também notável foi sua ocupação como Presidente da Sociedade Real Egípcia de Papirologia e sua amizade com Fuad I (1868-1936), sultão e posteriormente rei do Egito. A relação dos dois era tão próxima que Jouguet, em 1940, foi escolhido por Fuad para lecionar na Université Fouad du Cairo (Merlin, 1950, p. 406). Pela profícua carreira e caráter impoluto - chegou a ser descrito em seu obituário como um cientista que logrou êxito em sua carreira - "respeitando a ordem dos valores humanos e científicos na pesquisa pela verdade" (Peremans, 1950, p. 1577) ${ }^{5}$ - recebeu o título de doutor honoris causa pela Universidade de Bruxellas em 1947 e, em 1948, o de Commandeur de la légion d’honneur, a mais alta condecoração do governo francês, dada a indivíduos de serviços inestimáveis prestados à nação (Merlin, 1950, p. 406). Foi coberto de glórias que Jouguet faleceu a 9 de julho de 1949.

O imperialismo macedônio e a helenização do Oriente ${ }^{6}$ pertence à coleção "A evolução da humanidade", dirigida por Henri Berr, também encarregado de prefaciar a obra. Jouguet edifica sua narrativa usando tanto de vasta documentação primária quanto dos escritos de

\footnotetext{
${ }^{4}$ A edição usada será El imperialismo macedonico y la helenización del Oriente, de 1927, com tradução a cargo de F. L. de la Vallina y Argüelles.

5 "en respectant l'ordre des valeurs humaines et scientifiques à la recherche de la vérité". Todas as traduções são de minha responsabilidade, indicando, quando necessário, os originais nos rodapés.

${ }^{6}$ Visto que a obra não foi vertida para o português, apresento uma tradução livre de seu título.
} 
ilustres pesquisadores da Antiguidade, casos do alemão Ulrich Wilcken e do russo Mikhail Rostovtzeff. Embora carregue imperialismo estampado na capa de seu trabalho, Jouguet não demora em alertar que o conceito de império - o poder único que domina e unifica raças e cidades heterogêneas - é estranho ao helenismo (1927, p. 6). Nem mesmo as cidades de Atenas e Esparta chegaram a construir uma potência imperial, já que um dos traços mais indeléveis da cultura dos helenos, o individualismo, arruinaria por completo a ânsia de agrupar uma miríade de povos sob a sua égide: “(...) o verdadeiro imperialismo é de origem oriental" (1927, p. 6), sentencia o helenista.

À primeira vista, tal assertiva pode parecer contraditória quando cotejada à hipótese das analogias entre imperialismos antigos e modernos feitas na tentativa de justificar as práticas imperiais dos séculos XIX e XX. Para que isso não se dê, é necessário recordar as ferramentas citadas por Jouguet como fundamentais na constituição do império. Em seu entendimento, o imperialismo nasce de ambição e necessidades geográficas e econômicas que, por sua vez, levam à submissão de cidades vizinhas menos adiantadas (1927, p. 6). Assim, a máquina imperial avança apoiando-se em dois métodos centrais: conquista e diplomacia (1927, p. 7). Por diplomacia, fica nítido que o francês entende a rendição de bom grado dos territórios ao poderio imperial, dado o entendimento de que, por serem "menos adiantados", nada poderiam fazer diante de sua pujança. A formação do Império de Alexandre obedece a esta lógica de conquista sistemática e capitulações em massa.

Já no início de sua exposição, Jouguet declara que o outrora magnífico Império Persa estava em franco declínio quando do advento de Alexandre. O conquistador pode constatar logo ao primeiro encontro como estavam carcomidos os alicerces que sustentavam os domínios imperiais do Grande Rei (1927, p. 31). Segundo o historiador francês, os domínios asiáticos eram habitados por hordas nômades, incapazes de se agrupar em cidades. Mesmo quando o faziam, erigiam-se nada mais que cidadelas rústicas, menores e atrasadas (1927, p. 98). Em vistas ao quadro de derrocada persa e ascensão do imperialismo macedônio, render-se ao poderio dos exércitos de Alexandre parecia ser o mais sábio arbítrio, ao menos no entendimento do helenista francês.

O imperialismo macedônio que intitula o livro de Jouguet nasce tanto do poderio bélico quanto da luz da cultura da Grécia, carregada aos confins da Ásia para iluminar seus habitantes. Eis o helenismo para Jouguet: a benévola tintura que cobriu o Oriente com as cores da racionalidade grega, aspecto que será mais explorado no decorrer do artigo. Assim, se antes imperialismo era sinônimo de rendições sucessivas a poderes cada vez mais tirânicos, com Alexandre ele encontra um ponto de inflexão: trata-se agora de incorporar-se a uma sociedade superior. O imperialismo despótico do Oriente é abandonado em favor daquele pautado pela luz da civilização, tal parece ser a interpretação do helenista francês. Dado o contexto no qual foi escrito seu livro, torna-se impossível não se lembrar das palavras de Richard Hingley (2010, p. 71): "O saber clássico reinventa-se no mundo moderno para dar forma a um elemento vital de um crescente discurso de modernidade no qual as relações imperiais foram criadas e transformadas". 
Foi mencionado no parágrafo acima que Jouguet enxergava o helenismo como a cultura grega carregada desde a Hélade pelas conquistas de Alexandre. Na próxima seção, será discutido em pormenores como a ideia de helenismo era entendida pelo historiador francês, bem como investigado de que modo se deu sua difusão pelo Mundo Antigo.

\section{CONQUISTAR E HELENIZAR: A DIFUSÃo DA CULTURA GREGA NO ORIENTE}

Dito de maneira sintética, Jouguet interpretava o helenismo como a continuação da cultura da Grécia antiga, aquela louvada pelas epopeias de Homero e representada pelas peças trágicas de Ésquilo, Sófocles e Eurípides. Aquela que se proliferava por meio da educação formal obtida nos liceus e do racionalismo, da profundidade filosófica sem par de Platão e Aristóteles. Aquela da democracia de Péricles, responsável por fazer florescer a liberdade dos cidadãos atenienses. Aquela cultura da Grécia clássica marcada pela vida nas cidades, verdadeiro milagre nascido das ruínas palacianas após a queda das monarquias cretense e micênica. São elas, as cidades, as estrelas do helenismo trazido por Alexandre. São as póleis que conservam sempre seu caráter de representantes legítimas do helenismo (1927, p. 113).

Deste modo, Jouguet advoga que o helenismo nada mais era que a cultura helênica clássica que rompeu os limites da Hélade graças ao impulso promovido pelas conquistas de Alexandre. Sua marca primordial não era a promoção de uma convivência harmoniosa dos costumes estrangeiros e locais. Tratava-se, antes, de reunir sob a cultura grega vencedores e vencidos, conquistadores e conquistados (1927, p. 75). O helenismo é a pedra sobre a qual se edifica o Império de Alexandre, império no qual helenizar era a ordem do dia, intento só atingido por meio da fundação sistemática de cidades: “(...) O helenismo apenas podia propagar-se no mundo pelos focos múltiplos das cidades, únicos marcos possíveis da verdadeira vida helênica" (1927, p. 149). ${ }^{7}$

Mesmo os macedônios tiveram de se revestir da cultura grega antes de difundi-la pelo Mundo Antigo, uma vez que em seus territórios não havia o regime de cidades que caracteriza o helenismo (1927, p. 87). Seu sistema de governo estava nas mãos de chefes locais, sem a participação popular que Jouguet enxerga no século de Péricles. Assim, o helenista francês pondera que os macedônios se helenizaram antes de helenizar, algo verificável pelo fato de as classes "mais instruídas" adotarem o grego ático, "língua comum a todos os helenos" (1927, p. 95).

Por ora, é preciso deter-nos ao papel das cidades. Além de ser o núcleo vital da vida helenística, as póleis eram agentes da política de helenização, uma vez que a civilização grega estava tão ligada à vida urbana que seria impossível helenizar sem fundar cidades (1927, p. 90). Deste modo, a vida citadina seria por demais sedutora aos autóctones, que passariam a se helenizar tão logo notassem este fato, como Jouguet propõe no excerto abaixo:

\footnotetext{
${ }^{7}$ (...) "El helenismo solo podia propagarse en el Mundo por los focos multiplicados de las ciudades, únicos marcos posibles de la verdadera vida helénica”.
} 
(...) Os bárbaros (...) multidões sem coesão e sem iniciativa, dóceis ao comando de um senhor absoluto! A cultura helênica não poderia mudá-los até o ponto que também se habituassem a uma vida política, no sentido grego do termo, e o único meio de prepará-los para isto será fazer surgir por toda a parte cidades gregas, cujo esplendor, costumes e leis os atingiriam, civilizando-os (1927, p. 114). ${ }^{8}$

Conforme aponta Morris (1994, p. 7), considerar a fundação de cidades como prova da helenização é bastante comum; esse aspecto é desenvolvido de maneira mais profunda por Price (2001, p. 309), que defende ser esta uma prática resultante de mais analogias entre o Mundo Antigo e as aventuras coloniais da Europa moderna:

Na esteira das conquistas de Alexandre, os novos reinos consolidaram a expansão do mundo grego: os reis fundaram novas cidades, que garantiram o domínio grego sobre as culturas nativas. A conexão é visível aqui entre o poder político e o domínio cultural, numa interessante analogia com a disseminação da cultura europeia para as nossas colônias. ${ }^{9}$

As palavras de Price ficam ainda mais nítidas quando se recorda que a França foi uma das maiores potências imperiais, aumentando seu território em cerca de nove milhões de quilômetros quadrados (Hobsbawm, 2005, p. 91), utilizando quase sempre um "discurso civilizador com o intuito de justificar as colônias (...) na África e na Ásia” (Silva, 2007, p. 116). No caso francês, urgia que o discurso civilizador fosse ainda mais latente, visto que outros ícones imperialistas - em particular a Grã-Bretanha - viam holandeses, belgas e os próprios franceses não como gregos ou romanos, arautos da cultura, mas sim como fenícios, versados somente no comércio e pilhagem colonial (Alencastro, 2008, p. 160).

Diante do que foi exposto, parece ser plausível a hipótese de que Jouguet traçava paralelos entre as conquistas de Alexandre e as práticas imperialistas levadas a cabo sob o estandarte francês de modo a justificá-las, em consonância com a "atitude francamente política” que marcou os estudos Antigos, conforme proposto por Bernal (2005, p. 13). A fundação de cidades gregas no Oriente aparece em analogia com o estabelecimento das colônias francesas: ambos são instrumentos usados por culturas superiores para ilustrar rincões afastados. A helenização do Oriente e o imperialismo macedônio propostos por Jouguet se consubstanciam no florescimento urbano que faria florescer a cultura grega. À luz de tal conclusão, as palavras de Alcock (1994, p. 171-3) são lapidares:

\footnotetext{
8 “(...) Los bárbaros (...) multitudes sin cohesión y sin iniciativa, dóciles al mandato de um senõr absoluto! La cultura helênica no podrá cambiarlos hasta el punto de que ellos también se habitúen a una vida política, en el sentido griego de la palabra, y el único médio para prepararles a ello será hacer surgir por todas partes ciudades griegas, cuyo esplendor, costumbres y leyes les atraigan, civilizándolos". 9 "In the wake of Alexander's conquests the new kingdoms consolidate the expansion of the Greek world: the kings founded new cities which ensured the dominance of Greek over native cultures. The connection visible here between political power and cultural dominance has an interesting analogy in the spread of European culture to our colonies".
} 
Ilustração para as massas atrasadas, o dom de um governo superior, a adoção de uma linguagem comum (a koiné), e o estímulo econômico: "fardo do homem branco" europeu foi transferido (...). Em suma, muita história helenística é fundamentalmente história colonialista $(\ldots) .{ }^{10}$

Propugnada a tese das analogias entre o passado helenístico e o presente francês feitas por Jouguet, deve-se voltar à análise do protagonismo das cidades no entendimento do helenista. Além de serem os principais agentes da helenização, os núcleos urbanos tinham também outra missão: salvaguardar as práticas gregas daquele misticismo taciturno das terras do Oriente, conforme Jouguet deixa claro no excerto a seguir:

Nelas deveriam ser conservadas e transmitidas as tradições da cultura grega, vinculadas às concepções dos antigos do espírito da cidadania. Importava, pois, fomentar este espírito e resguardá-lo das influências deletérias que este meio oriental ameaça por todos os lados (1927, p. 407). ${ }^{11}$

A manutenção de uma suposta pureza das práticas culturais da Grécia é outra das obsessões do helenista francês. Além da instituição de cidades, Jouguet saúda a prática de os gregos radicados no Egito se agruparem em torno de seus pares de maneira a "conservar mais fielmente as tradições de sua raça” (1927, p. 420), assertiva que parece mais pungente quando se recorda que na França de finais de século XIX e início do XX havia um crescimento de sentimentos antissemitas (Arendt, 2013, p. 85) e xenófobos, devido à migração em massa de belgas, judeus e italianos (Perrot, 2009, p. 16-7). Em vista de o racismo muitas vezes ter sido justificado por meio da apropriação do passado Antigo (Bernal, 1987 passim), parece ser crível conjeturar que há alguma conexão entre o cenário político francês vigente à época de Jouguet e suas teses a respeito do papel da cultura grega no Oriente. Uma vez que a circulação de saberes e produção de regimes de verdade estão sempre envoltas às redes discursivas do presente (Foucault, 2014), a ligação entre o presente francês e o passado grego parecer ser uma das mais notáveis preocupações de Jouguet.

As hipóteses levantadas no parágrafo acima se tornam mais plausíveis à medida que se recorda, como quer Hobsbawm (2005, p. 107), que a França "acreditava transformar seus súditos em franceses", ao passo que Jouguet propõe que o mesmo processo foi liderado pelos greco-macedônios na Ásia. Fundar cidades e estabelecer colônias para converter os nativos à gramática civilizacional dos conquistadores. Eis o ditame de franceses e grecomacedônios, antigos e modernos:

\footnotetext{
10 "Enlightenment for the backward masses, the gift of superior government, adoption of a common language (the Greek koine), and economic stimulation: the European 'white man's burden' was transferred (...). In short, much Hellenistic history is fundamentally colonialist history (...)".

11 "En ellas debían conservarse y transmitirse las tradiciones de la cultura griega, vinculadas en las concepciones de los antiguos al espíritu de ciudanía. Importaba, pues, fomentar este espíritu y resguardarle de las influencias deletéreas que en este medio oriental le amenzaba por todas partes".
} 
O helenismo se baseia no regime da cidade e este, em última instância, na pessoa do cidadão, isto é, do homem livre, senhor de si e de sua terra, submetido unicamente às leis, que são, em parte, expressões de sua vontade. No Oriente, o Estado tende, em geral, a concentrar-se na pessoa de um rei de direito divino, e este Estado todo poderoso é dono de seus súditos, de seus corpos e bens. O cidadão se devota inteiramente à sua pátria, a lei às vezes pode ser um tirano inexorável, mas ao menos a obediência que impõe não tem nada de servil, e, além de tudo, por atrás do cerco em torno de sua casa, sobre aquele pedaço de solo nacional, que é seu sem restrições, o cidadão heleno exerce amplamente sua liberdade (Jouguet, 1927 [1926], p. 496). ${ }^{12}$

A já aludida preocupação do helenista francês com uma suposta 'pureza' da cultura grega fica ainda mais clara na sequência. Jouguet propõe que o helenismo, não obstante seus esforços, acabou maculado - ao menos em parte - pelas práticas bárbaras que povoavam a Ásia. Se por um lado as conquistas de Alexandre fizeram com que a cultura da Grécia se expandisse, por outro, tal expansão acabou se defrontando com infortúnios. O helenismo genuíno trazido pelas falanges acabou não se defendendo de maneira exitosa e terminou corrompido:

Se o helenismo tivesse concentrado mais suas forças, acaso poderia assegurar-se de uma existência ao menos tão duradoura e mais vigorosa; organizado mais estritamente, acaso teria se difundido menos pelo mundo e teria se defendido melhor do que teve de influência do Oriente, que foi deletério para seu verdadeiro espírito (Jouguet, 1927 [1926], p. 151)..$^{13}$

No entender de Jouguet, mesmo a postura de Alexandre Magno acabou contaminada pelo Oriente: assim como a personagem Kurtz, ${ }^{14}$ do romance O Coração das Trevas (1899), de

\footnotetext{
12 "Se basa el helenismo en el régimen de ciudad y este, en último termino, en la persona del ciudadano, esto es, del hombre libre dueño de si y de su tierra, sometido únicamente a las leyes, expresión en parte de su voluntad. En Oriente el Estado tiende en general a concentrarse en la persona de um Rey de derecho divino, y este Estado todo poderoso es dueño de sus súbditos, de sus cuerpos y bienes. El ciudadano se debe ciertamente por entero a su pátria y la ley puede a veces ser un inexorable tirano; pero al menos la obediencia que impone no tiene nada de servil, y, por lo demás, detrás del recinto que rodea su hogar, sobre la parcela de aquel suelo nacional, que es suya sin restricciones, el ciudadano heleno ejerce ampliamente su libertad (...)".

13 "Si el helenismo hubiera concentrado más sus fuerzas, acaso habría podido asegurarse una existencia al menos tan duradera y más vigorosa; organizado más estrechamente, acaso se hubiera difundido menos por el Mundo y se hubiera defendido mejor de lo que en la influencia del Oriente fué deletéreo para su verdadero espíritu".

${ }^{14}$ De acordo com o romance, Kurtz era um eficiente negociante de marfim, enviado ao Congo Belga com a missão de obter mais proventos financeiros para o reino de Leopoldo II. Todavia, ao mergulhar nas profundezas da densa floresta africana - o coração das trevas - Kurtz é tragado pelo
} 
Joseph Conrad, ou o general francês e agente no Marrocos, Hubert Lyautey (1854-1934), ${ }^{15}$ o macedônio deixou-se seduzir pelos costumes estrangeiros. Se antes era o monarca do mundo - e o helenismo a joia mais brilhante de sua coroa -, após assenhorear-se do reino Persa, sua grandiosidade feneceu, fazendo com que ele deixasse de zelar pelo helenismo, a razão de sua vitória. Assim, Jouguet interpreta o sentar de Alexandre no trono do Grande Rei como uma demonstração de insolência, incompatível com seu antigo caráter. Abancar-se naquele trono faria com que Alexandre se tornasse um simples sucessor de Dario, ou seja, um déspota de infame laia:

Pelo menos veriam muito claramente que Alexandre, desde que se assentou no trono dos Grandes Reis, parou de se comportar apenas como macedônio e grego. A partir do momento que herdou o Império não seria verdade dizer que deixou de cuidar do helenismo, mas sim que o helenismo não é o único em seus cuidados. Pelo contrário, parece outro Dario (1927, p. 152). ${ }^{16}$

Entretanto, por mais que houvesse alguns reveses - como a transformação de Alexandre em um autêntico monarca oriental - Jouguet ainda considerava que o triunfo da cultura grega no Oriente foi inspirador. E, de acordo com o helenista francês, o local onde mais se poderia colher seus frutos era o Egito, onde a luz do formidável farol de Alexandria iluminaria com a sabedoria grega, lídima matriarca dos saberes ocidentais modernos, todos os rincões, todo o mundo conhecido.

Não é demais lembrar que os olhos imperialistas franceses pousavam sobre os territórios egípcios ao menos desde o advento de Napoleão. E é sobre a helenização do Egito que Jouguet discorre na sequência de sua obra. O helenista, que em seu doutoramento já havia estudado o Egito sob os romanos e tinha vasto conhecimento de papirologia, escolhe investigar de maneira mais pormenorizada os domínios ptolomaicos, devido tanto à abundância de documentação quanto ao fato de os lágidas serem os diádocos que mais se esforçaram em levar à frente a política de helenização (1927, p. 224). Sendo assim, a última preocupação deste artigo será apresentar e analisar as formas através das quais Jouguet advogava em favor do triunfo da cultura grega sobre o Egito.

ambiente de forma inconversível, passando a viver entre os nativos como uma espécie de semideus, abandonando sua missão basilar.

${ }^{15}$ Lyautey era um general do exército francês, que serviu no Marrocos entre os anos de 1912 a 1925. Responsável por "pacificar" a colônia, um de seus métodos mais conhecidos era o de manter as tradições locais, de forma a mitigar as revoltas autóctones. Era comum, durante seu jugo, o hastear da bandeira marroquina e o entoar seu hino, fato que desagradava a alguns setores da alta cúpula da França (Singer, 1991).

16 "Al menos verían clarísimamente que Alejandro, desde que se sentó en el trono de los Grandes Reyes, dejó de conducirse únicamente como macedonio y griego. Desde el momento en que heredó el Imperio, sí no sería cierto el decir que ya no se cuidó de helenismo, sí lo es que el helenismo no es el único de sus cuidados. Más bien parece otro Darío" (1927, p. 152). 


\section{A Helenização do ORIENTE A PARTIR do CASO EGÍPCIO}

As terras faraônicas, de milenares deuses e costumes, eram controladas pelo brutal jugo dos reis persas. O Egito, que já havia sido conquistado por Cambises - e reconquistado por Artaxerxes III - perecia por carregar os grilhões aquemênidas. Em um cenário de esqualidez, o advento de Alexandre e seus sucessores foi um sopro de liberdade. O helenismo trazido pelos lágidas se encarregaria de desafogar os nativos da opressão persa. É desta maneira que Jouguet interpreta a chegada de Alexandre ao Egito, o advento de um libertador que foi acolhido e saudado pelos egípcios, em uma interpretação bastante comum na historiografia (Bakos, 2008).

Devido às seculares tradições faraônicas, a política de helenização no Egito deveria ser ainda mais pujante, sob a pena de o helenismo ser engolido pelos costumes dos vencidos (Jouguet, 1927, p. 169). Afinal, de acordo com o historiador francês, quaisquer interações entre o helenismo e as culturais locais seriam deletérias para a primeira. Jouguet estabelece uma rígida hierarquia entre a cultura da Hélade e os cultos egípcios; se há qualquer espécie de sincretismo - conceito complexo e aqui usado de maneira arbitrária para se referir a interações entre diferentes tipos de práticas religiosas -, os resultados são simples: quando o culto estrangeiro se sobrepõe ao local, temos a helenização, louvável sob as lentes de Jouguet. Se o inverso ocorre, o que se sucederá será a uma contaminação do helenismo:

Da influência do Oriente não se deve duvidar, porque à medida que os gregos são atraídos por ele, mais os seduz o culto dos reis, e, em contrapartida, na Europa não ocorre nada semelhante; mas o Oriente influiu, sobretudo, envolvendo os espíritos em uma atmosfera mística. É digno de nota como os ritos egípcios apenas modificam o culto helênico, ao passo que este produz efeitos até nos templos egípcios e no nome solar dos reis. Deste ponto de vista, as ideias gregas e egípcias parecem se enlaçar sem se confundir (1927, p. 377). ${ }^{17}$

Como se nota no parágrafo acima, Jouguet interpreta que, a despeito das tais "seduções", a cultura grega exulta, helenizando templos, costumes e divindades. Um exemplo encontra-se no culto em homenagem ao deus Ápis. De acordo com a tradição religiosa egípcia, Ápis é o touro em que Osíris reencarna. A continuação deste culto nos tempos dos lágidas só se deu, de acordo com Jouguet, após Ápis ter sido revestido de um manto

\footnotetext{
17 "De la influencia del Oriente no cabe dudar, porque a medida que los griegos son atraídos por él, más les seduce el culto de los reyes, y, en cambio, en Europa no ocurre nada semejante; pero el Oriente influyó, sobretodo, envolviendo los espíritus en una atmosfera mística. Es de notar cómo los ritos egípcios apenas modifican el culto helénico, al paso que este produce efectos hasta en los templos egípcios y en el nombre solar de los reyes. En esta matéria las ideas griegas y egípcias parecen enlazarse sin confundirse".
} 
helênico: "Os gregos adotaram este culto e o helenizaram, dando ao Ápis morto a forma de Plutão, a quem deram o nome de Serápis” (1927, p. 304). ${ }^{18}$

A suposta transformação de uma divindade egípcia em grega ilustra como a helenização operava no pensamento de Jouguet: quando os gregos aderem a um culto ou divindade egípcios, tomam a precaução de o helenizarem antes, maquiando-o com aspectos helênicos. Quando os egípcios adotam práticas gregas, o fazem de modo acrítico, assimilando de maneira passiva costumes, cultos e nomes. Não por caso, a nomenclatura dos bairros das novas cidades fundadas pelos ptolomeus - tais como Arsinoe, Hermópolis e Oxirinco - provaria, de acordo com Jouguet, a sobreposição da cultura grega sobre os costumes egípcios (1927, p. 347).

Outro subterfúgio usado para fazer exultar a helenização eram movimentos migratórios sistemáticos, que concorriam de maneira decisiva para o progresso econômico (1927, p. 413). A migração associada ao crescimento econômico também parece ecoar as analogias entre cidades gregas e colônias francesas, ainda mais quando o helenista assinala que para se organizar finanças, cunhar moedas e aumentar a produção eram necessários o espírito metódico e as capacidades técnicas que somente o helenismo podia proporcionar (1927, p. 360). O progresso do Egito só poderia ser alcançado mediante o rigor lógico da inteligência grega (1927, p. 409). O advento de Alexandre é ponto de inflexão na história das terras banhadas pelo Nilo, que outrora se encontravam no atraso institucional típico do Oriente, com suas potencialidades envoltas em um sono que só seria desbaratado com a helenização. Se uma das máximas de Heródoto diz que o "Egito é uma dádiva do Nilo", Jouguet poderia alterar a fórmula e alardear que o "Egito é uma dádiva de Alexandre e da helenização", em uma linha teórica que se tornou contumaz, conforme defende Silva (2010, p. 427):

A dominação de Alexandre e o helenismo, e, posteriormente, a conquista romana foram inseridos como marcos significativos na história do Egito, representando momentos de ruptura, traduzidos no vocabulário historiográfico como sinônimos de progresso, evolução (...).

Deste modo, a fundação de cidades, a presença de divindades gregas e o florescimento econômico constituiriam um discurso de progresso indiscutível que seria muito sedutor para que os autóctones resistissem. A difusão do helenismo, assim, tem dois momentos distintos e complementares: o primeiro é a edificação extensiva de cidades que tinham o duplo propósito de espraiar as tradições da Hélade e salvaguardá-la das práticas orientais. A fundação de cidades era uma preparação indispensável para que o helenismo brotasse em ambiente tão árido. Concluída esta etapa, o resto seria conseguido sem esforço: os núcleos citadinos atrairiam imigrantes, fariam com que se desenvolvessem as finanças, que o helenismo prosperasse.

18 "Adoptaron los griegos este culto y le helenizaron, dando al Apis muerto la forma de un Plutón, que tomó el nombre de Serapis". 
Não obstante, era necessário, para além da política de helenização, criar mecanismos para defender a cultura grega das tradições orientais. A mais eficiente para Jouguet era a proibição de casamentos entre gregos e egípcios:

Havia sido, indubitavelmente, uma medida prudente proibir os cidadãos das populações gregas no Egito de se casar com as indígenas; deste modo, se conservava mais pura a fonte do helenismo; mas havia sido impossível proibir uniões semelhantes entre os gregos estabelecidos no campo, e um paradoxo, se realmente havia o desejo de helenizar o Egito. $(1927 \text {, p. } 429)^{19}$

É revelador no trecho acima uma posição de Jouguet - mais uma vez preocupado com a manutenção de uma suposta pureza cultural grega - que chega quase às raias do racismo explícito, também marca indelével do discurso imperialista moderno (Bagnall, 1997, p. 230). Oportuno lembrar que esta retórica, em dada medida, também marcou outro conhecido especialista francês em Antiguidade, Carcopino, ${ }^{20}$ o que mostra como Jouguet não estava sozinho em suas teses a respeito do papel da cultura grega no Oriente, nem, tampouco, era o único pesquisador que enxergava ligações entre o 'papel civilizador' de gregos e romanos para com o Oriente e a mesma missão que deveria ser levada a termo pelos franceses.

$\mathrm{Na}$ verdade, diversos outros pesquisadores, em âmbito francófono ou não, tinham posições semelhantes às de Jouguet. No que diz respeito à economia, um exemplo é $A$ Social and Economic History of the Hellenistic World, obra lançada em 1941 por Mikhail Rostovtzeff, que enxergava o crescimento econômico promovido pelos gregos na Ásia como o traço mais marcante do período helenístico. ${ }^{21}$ Já a preocupação com as influências deletérias que a cultura da Ásia, e, em particular, a do Egito, traria ao helenismo aparece nas palavras de

\footnotetext{
19 "Había sido indudablemente una prudente medida prohibir a los ciudadanos de las poblaciones griegas de Egipto casarse con las indígenas; de este modo se conservarba más pura la fuente del helenismo; mas habría sido impossible prohibir semejantes uniones a los griegos establecidos en el campo y un contrasentido si realmente se queria helenizar el Egipto".

${ }^{20}$ Jerôme Carcopino $(1881$ - 1970) foi um historiador francês que ocupou o cargo de secretário de Estado durante o Regime de Vichy, governo que não considerava o estado de direito e que vigorou na França de fevereiro de 1941 a abril de 1942. Autor do clássico La vie quotidienne à Rome à l’apogée de L'Empire, muito se pergunta a respeito das formas como sua participação em regime autoritário pode ter influído em suas elocuções sobre o Mundo Antigo (Silva, 2007; Funari, 1992).

${ }^{21}$ Defende o historiador russo que "The economic potentialities of Egypt were very great, but the pace of economic activity was slow, as in most oriental countries” (1941, p. 264). Sua retórica parece tão marcada pela experiência colonialista europeia que Rostovtzeff não se furta em estabelecer relações diretas entre este período e a Antiguidade: "The regime of the early Ptolemies in Egypt (...) reminds us to a certain extent of that established in modern times by European countries in their colonies, especially in the early period of European colonial development. The relations of the European to the natives at the time were these of domination rather than association, and the aim of the colonizers was in the main the exploitation of the colonized territory for their own material benefit" $(1941$, p. 326).
} 
Bell, ${ }^{22}$ em artigo publicado em 1922: "the spirit of Hellenism, that mental freedom, that fullness of humanity (...) which are the glory of Hellas, could not but wither in such an atmosphere" (Bell, 1922, p. 146).

Ainda que não se possa cometer generalizações e condenar toda uma geração de historiadores - como se sua única característica fosse enxergar semelhanças entre as culturas grega e romana e sua salutar herança no Ocidente e Oriente - é preciso notar como parte da produção sobre a Antiguidade realizada durante o final do século XIX e início do XX é marcada por aspectos do cenário político vigente, manifesto pela preocupação com temos como 'evolução', 'romanização', 'helenização', 'civilização', 'raça' e outros de teor semelhante.

No caso de Jouguet, a louvação das práticas culturais da Hélade é tão grande que o historiador francês não se furta a acenar para o risco de "abastardamento" caso os gregos das khórai ptolomaicas - núcleos habitados por "semi-helenos" que estudavam os clássicos e Homero, mas escreviam o grego clássico de maneira cada vez mais incorreta (1927, p. 433) - se unissem àqueles das verdadeiras cidades, cenário por excelência da vida helênica. Este enlace matrimonial faria com que as tradições helênicas fossem degradadas, de tal forma que Jouguet completa seu raciocínio com uma máxima de Ernest Renan que fala por si: "O filho de uma oriental e um europeu é um oriental" (1927, p. 433).

\section{CONSIDERAÇÕES FINAIS}

Conforme apresentado, Jouguet tem visões particulares sobre a definição de helenismo, visto por ele não como uma nova cultura nascida do contato entre grecomacedônios e autóctones, mas sim a continuação das práticas culturais da Grécia clássica que foram carregadas ao Oriente graças à expansão territorial promovida por Alexandre. Assim, o conquistador macedônio e os diádocos produziram não um imperialismo despótico como aquele levado a cabo pelos Grandes Reis, mas um pautado pelo poderio bélico e, principalmente, pela ilustração intelectual. Deste modo, o Império Macedônio gera a helenização do Oriente, difundindo a cultura grega, antes confinada à Hélade, a todos os confins da Ásia. Esta linha interpretativa aparenta possuir consonâncias com o moderno imperialismo europeu, que alardeava levar civilização e progresso a paragens exóticas tais como aquelas de um Oriente estanque e indiferenciado.

Se estes discursos sobre o passado Antigo e o imperialismo moderno eram comuns - como visto nos parágrafos acima -, no caso de Jouguet são notáveis as louvações a uma suposta cultura grega 'pura' feitas pelo autor. A visão presente nos esquemas de Jouguet a respeito do encontro entre o mundo ocidental - representado por Alexandre e o helenismo e a Ásia repete os ecos de uma tradição historiográfica eurocêntrica estabelecida no período em que Jouguet deu vida aos seus escritos, conforme defendido por Funari (2003b, p. 100):

\footnotetext{
${ }^{22}$ Sir Harold Idris Bell, historiador britânico especialista em papirologia do Egito Romano, recebeu diversas honrarias como Officer of the Order of the British Empire (1920), Companion of the Order of the Bath (1936) e o título de sir em 1946. Seus escritos são citados várias vezes por Jouguet ao longo de sua obra.
} 
(...) $\mathrm{Na}$ História Antiga, a tradicional dicotomia entre Oriente e Ocidente constitui uma grande narrativa que estrutura toda uma visão eurocêntrica da História. Cada vez mais apresenta-se essa oposição no contexto histórico do moderno imperialismo do século XIX e XX, a mostrar como o Ocidente se cria como uma supercivilização dominadora do mundo. Em um primeiro momento, este Ocidente é nitidamente racista, arianista, anti-semita, ao criar um homem ariano ocidental racional, guerreiro e conquistador do oriental irracional, trapaceiro, indolente, pronto a ser civilizado pelos arianos (alemães, franceses, e depois americanos).

O raciocínio é retomado em outro texto pelo mesmo autor, citando o próprio Jouguet com um estudioso que fazia uso de tinturas modernas para colorir o Mundo Antigo:

Na historiografia contemporânea inventa-se (...) um Oriente em tudo oposto ao Ocidente, irracional, imutável, entregue ao despotismo e cuja libertação dependia da ação providencial do discurso lógico, da racionalidade e da retórica ocidentais, filhas da Grécia Clássica. Ao longo das décadas de domínio colonial até a descolonização dos anos 1960 fazia-se uma analogia entre a ação civilizadora dos europeus e a vitória helênica sobre o Oriente, como Pierre Jouguet deixava claro (...) (Funari, 2004, p. 3).

Tais conotações mencionadas por Funari talvez apareçam de forma mais clara em O imperialismo macedônio e a helenização do Oriente em sua conclusão, quando Jouguet escreve:

O helenismo conquistou o Oriente com armas da Macedônia e com suas próprias instituições (...). É sem dúvida um maravilhoso espetáculo contemplar a civilização grega difundida para espaços tão vastos e por tantos países novos abertos à curiosidade e à atividade do Ocidente. (...) Não resta dúvida que a civilização ocidental se baseia na concepção grega e que é resultado do livre desenvolvimento das iniciativas individuais. Já no tempo de Alexandre ela havia demonstrado sua superioridade (1927, p. 493, 495, 497). ${ }^{23}$

Diante desta citação, do entendimento de Jouguet das cidades gregas como mananciais dos quais se poderia sorver o doce néctar de uma cultura superior - em clara analogia com as colônias francesas - e com vistas a toda a argumentação apresentada, parece ser admissível alegar que o helenista francês, embora se voltasse à Antiguidade, sempre tinha o presente em sua alça de mira.

23 “El helenismo conquistó el Oriente con las armas de Macedonia y com sus próprias instituciones (...). Es sin duda maravilloso espectáculo contemplar la civilización griega difundida por tan vastos espacios y tantos países nuevos abiertos a la curiosidade y la actividad del Occidente(...). No cabe duda de que la civilización occidental se basa en la concepción griega y que es el resultado del libre desenvolvimiento de las iniciativas individuales. Ya en tempo de Alejandro había demostrado su superioridad". 


\section{REFERÊNCIAS}

ALCOCK, S. Breaking up the Hellenistic world: survey and society. In: MORRIS, I. Classical Greece: ancient histories and modern archaeologies. New York: Cambridge University Press, 1994, p. $171-190$.

ALENCASTRO, L. Persistência das Trevas. In: CONRAD, J. Coração das trevas. São Paulo: Companhia das Letras, 2008.

ARENDT, H. As origens do totalitarismo. São Paulo: Companhia das Letras, 2013.

BAGNALL, R. Decolonizing Ptolemaic Egypt. In: CARTLEDGE, P.; GARNSEY, P.; GRUEN, P. (org.). Hellenistic constructs: essays in culture, history, and historiography. Berkeley: University of California Press, 1997.

BAKOS, M. Visões modernas sobre o mundo Antigo: a Egiptologia. In: FUNARI, P. P. A.; SILVA, G.; MARTINS, A. (org.). História antiga: contribuições brasileiras. São Paulo: Annablume, 2008.

BELL, H. Hellenic Culture in Egypt. The Journal of Egyptian Archaeology, vol. 8, n.3-4, p. 139155, 1922.

BERNAL, M. A imagem da Grécia Antiga como uma ferramenta para o colonialismo e para a hegemonia européia. Textos Didáticos - Repensando o Mundo Antigo. IFCH/UNICAMP, n. 49, p. 13-31, abril 2005.

BERNAL, M. Black Athena: the Afroasiatic roots of classical civilization. London: FAB, 1987.

CONRAD, J. Coração das trevas. São Paulo: Companhia das Letras, 2008.

FOUCAULT, M. A arqueologia do saber. São Paulo: Forense Universitária, 2014.

FUNARI, P. P. A. Retórica e argumentação, do mundo clássico ao nosso quotidiano. História e-História, p. 1-4, 2004.

FUNARI, P. P. A. A renovação no ensino de História Antiga. In: KARNAL, L. (org.) História na sala na aula. São Paulo: Contexto, p. 95-107, 2003.

FUNARI, P. P. A. Doxa e Episteme: a construção discursiva na narrativa histórica (ou Salústio e a Historiografia). Revista de História (UFOP), v. 3, p. 22-35, 1992.

HAMMOND, M. Ancient Imperialism: Contemporary Justifications. Harvard Studies in Classical Philology, vol. 58-59, p. 105-161, 1948.

HINGLEY, R. O imperialismo romano: novas perspectivas a partir da Bretanha. São Paulo: Annablume, 2010.

HOBSBAWM, E. A era dos impérios, 1875-1914. Tradução de Sieni Maria Campos e Yolanda Steidel de Toledo. Rio de Janeiro: Paz e Terra, 2005. 
JOUGUET, P. El imperialismo macedonico y la helenización del oriente. Traducción del F. L. de la Vallina y Argüelles. Barcelona: Cervantes, 1927.

MERLIN, A. Notice sur la vie et les travaux de M. Pierre Jouguet, membre de l'Académie. Comptes rendus des séances de l'Académie des Inscriptions et Belles-Lettres, Année 1950, vol. 94, n. 4, p. 392-406.

MORRIS, I. Introduction. In: MORRIS, I. Classical Greece: Ancient Histories and Modern Archaeologies. New York: Cambridge University Press, 1994, p. 7-44.

PEREMANS, W. Pierre Jouguet (1869-1949). Revue Belge de Philologie et d'Historie, tome 28, fasc 3-4, p. 1576-1577, 1950.

PERROT, M. Outrora, em outro lugar. In: PERROT, M. (org.) História da Vida Privada 4: da Revolução Francesa à Primeira Guerra. São Paulo: Companhia das Letras, 2009.

PINTO, R. Duas Rainhas, um Príncipe e um Eunuco: gênero, sexualidade e as ideologias do masculino e feminino nos estudos sobre a Bretanha Romana. Tese (Doutorado em História), Programa de PósGraduação em História, Universidade Estadual de Campinas, Campinas, 2011.

PRICE, S. The History of the Hellenistic Period. In: BOARDMAN, J.; JASPER, J.; MYRRAY, O. The Oxford History of Greece and the Hellenistic World. Oxford: Oxford University Press, 2001.

ROSTOVTZEFF, M. The Social \& Economic History of the Hellenistic World. Oxford: Clarendon Press, 1941.

SAID, E. Cultura e imperialismo. Tradução de Denise Bottmann. São Paulo: Companhia das Letras, 1995.

SILVA, G. História Antiga e usos do passado: um estudo das apropriações sob o regime de Vichy (19401944). São Paulo: Annablume-Fapesp, 2007.

SILVA, T. O Orientalismo e o Helenismo: O Egito Antigo e o gênero no mito da civilização. Anais do I Congresso Internacional de religião, mito e magia no Mundo Antigo \& IX Fórum de debates em História Antiga. Universidade do Estado do Rio de Janeiro, Rio de Janeiro, 2010.

SINGER, B. Lyautey: An Interpretation of the Man and French Imperialism. Journal of Contemporary History, vol. 26, n. 1, p. 131-157, 1991.

VIDAL-NAQUET, P. Os gregos, os historiadores, a democracia: o grande desvio. Tradução de Jônatas Batista Neto. São Paulo: Companhia das Letras, 2002.

ZEILLER, J. Éloge funèbre de M. Pierre Jouguet, membre de l'Académie. Comptes rendus des séances de l'Académie des Inscriptions et Belles-Lettres, Année 94, n. 4, p. 213-219, 1949.

Recebido em 20 de março de 2016

Aprovado em 11 de junho de 2017 